\title{
The Department of Animal Genetics, University of Edinburgh.
}

THE scheme formulated in 1911 by the Development Commission for the further development of agricultural education and research included the creation of a number of research institutions. To Edinburgh was allotted an Institute of Research in Animal Breeding, and in 1913 a Joint Committee, including representatives of the University and of the College of Agriculture, was called into being. Its activities were completely interrupted by the War, and it was not until 1919 that they were resumed. It public bodies, including the Development Commission, the Empire Marketing Board, the Highland and Agricultural Society, and the University Court, this sum was raised or guaranteed. Plans of a new building were prepared by Messrs. Lorimer \& Matthew, and building operations were commenced in September 1928.

The new building is situated to the west of the Chemistry block and has the form of a $T$ with the cross-bar and the main entrance frontage, 91 feet long,

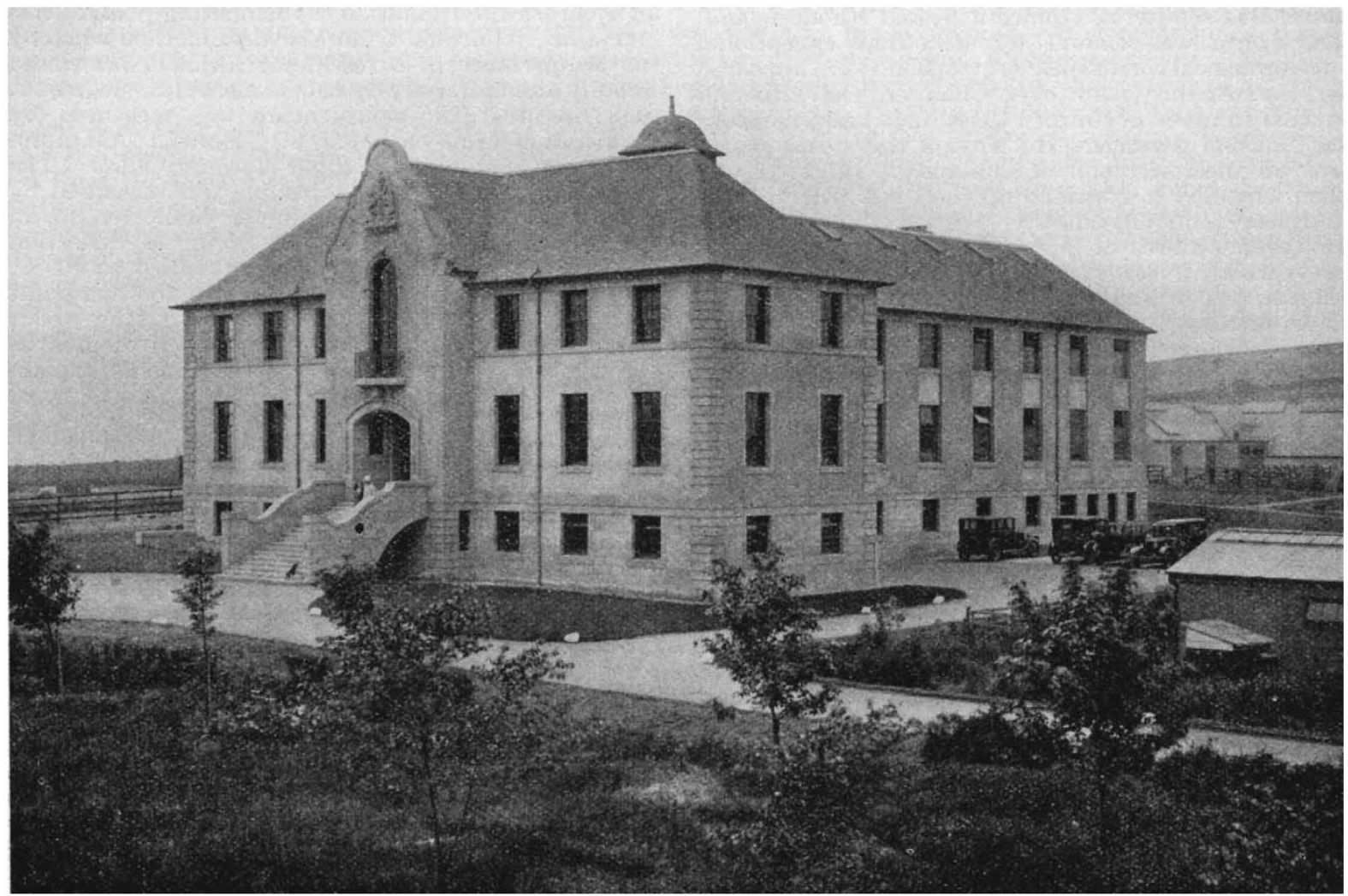

FIG. 1.--Department of Animal Genetics, University of Edinburgh.

was decided, owing to the general uncertainty which prevailed at this time, to make a very unambitious beginning.

The first home of the Department was an old fever hospital in the High School Yards, placed at the disposal of the committee by the University authorities, but by 1924 this accommodation had become entirely inadequate, not only for the experimental animals, but also for the staff and their guests. Emeritus Professor Sir James Walker placed seven rooms in the new Chemistry Department at King's Buildings at the disposal of the Joint Committee, and the University Court granted the use of seven acres of grass land.

In 1927 , as a result of a report made by its representative, the International Education Board of America granted a sum of $£ 30,000$ toward the building and equipment of the Department, and the endowment of a chair in animal genetics in the University. This offer was conditional on a like amount being raised from other sources, and on the provision of funds adequate for maintenance. Through the generosity of private individuals, notably Lord Woolavington, Lord Forteviot, and others, and of facing due east. It measures 140 feet from east to west, and consists of four floors, including a so-called basement and excellent attic accommodation, these being as well lighted and serving as useful purposes as do the ground and first floors. A feature has been made of the centre of the symmetrically treated front. The entrance doorway is recessed under a wide low arch and is approached by a flight of steps and flanked by shaped parapet walls, the whole being surmounted by a shaped gable after the Dutch style, having carved upon it a symbolical group representing the continuity of life.

The building is harled with stone facings and corners and the roof is covered with Ballachulish slates. All the floors are of reinforced concrete and in the corridors they are covered with terrazzo. The lecture theatre with its barrel vault carried up into the roof space is well lighted and is seated for 120 . The principal staircase is constructed in synthetic stone and has a simple but very fine wrought iron railing with ornamental panels.

On the ground and first floors are the rooms of the staff and of the guests. In the basement are the

No. 3167 , VoL. 126] 
constant temperature and X-ray rooms, animal rooms, staff common room, workshop, store room, lavatories, and also an unloading room in which packages can be transferred from a lorry directly into the electric lift which serves all floors. A caretaker's house of five rooms occupies the west end of the floor. In the attic, which runs the whole length of the building, are the aquarium, aviary, terrarium, and store room.

In the entrance hall are panels framed in oak with the names of students who have taken higher degrees whilst guests of the Department. At the top of the panels there is carved "De fructibus suis agnoscebantur." Under this honours panel there is an oak table and stools.

The heating of the Department is by low pressure steam.

In addition to this main block there lies, to the south-west, a sheep building provided by the Empire Marketing Board and equipped with operating theatre, sterilising and instrument rooms, food stores, and sheep pens. To the north-west there is a large brick intensive poultry house accommodating 200 birds. To the north there are the large pig building and goat house provided by the Department of Agriculture for Scotland. Several wooden buildings house the rabbit, rat, and mouse colonies, whilst others accommodate the monkeys and fowls.

The new building was officially opened on Monday, June 30, by the first chairman of the Joint Committee on Research in Animal Breeding, Sir Edward SharpeySchafer, president of the Royal Society of Edinburgh. At the opening ceremony, the degree of Doctor of Laws, honoris causa, was conferred by the ViceChancellor, Sir Thomas Holland, upon Mr. T. B. Macaulay, the president of the Sun Life Assurance Company of Canada, a Canadian with strong Scottish connexions, who has shown considerable interest in the affairs of the department and has endowed therein a lectureship and several assistantships.

\section{The Museums Association and Museum Extension.}

$\mathrm{T}$ forty-first annual conference of the Museums Association, which met at Cardiff, on June 23-27, by invitation of the Lord Mayor and Corporation and of the National Museum of Wales, was successful in all aspects. It was attended by more than 230 delegates and other members from all parts of the British Isles, as well as from the United States, Germany, and Sweden; these represented all classes of museums, from the great national institutions to the smallest village museums. The last statement strikes the main note of the conference : the knitting up of the museum service of the country and its extension to the remoter districts, a subject on which valuable discussions took place. The National Museum of Wales has itself set a brilliant example of such work, and, with its beautiful building and admirable arrangement, formed an inspiring focus of the proceedings. The guidance of its officers, the hospitality of the Lord Mayor, of the Mayors of Newport and Merthyr Tydfil, of Lord Treowen, and of numerous friends combined with the fine weather and the charm of the surrounding country to make the stay of the visitors as delightful as it was profitable.

The president, Sir Henry Miers, referred in his address first to the Report of the Royal Commission on National Museums and discussed the suggestions which it made for the co-operation of the Museums Association. In the event of a Standing Commission being appointed, it was hoped that the Association would have official representation on it. The proposed enlargement of the Circulation Department to include all suitable classes of museum material would be an important factor in co-ordinating museums, while the extension of the method of affiliation adopted by the National Museum of Wales should assist in their co-operation. Plans for a training course, as desired by the Royal Commission, were already published in the Museums Journal, and it was hoped that municipal bodies would assist their junior officers to attend. The scheme for a National Open-Air Folk Museum was making good progress in the hands of a strong committee.

Turning to the proposals of the Carnegie Trustees, the president said that the advice of the Association would be asked when grants were allotted to museums; it was necessary that museums should fulfil the conditions laid down in his own published report to the trustees; meanwhile museums might consider plans of work to which they might apply any possible grant. For the Association to perform the duties requested of it by the Royal Commission and by the Carnegie
Trustees, it was necessary that it should acquire a legal status ; as a first step it was proposed " that the Museums Association be converted into a Company, limited by guarantee and not having a share capital." This, with the consequent changes in the constitution of the Association, was accepted by the subsequent general meeting, which fixed the amount of the guarantee at $10 \mathrm{~s}$. for each member.

Finally, the president repeated some of his previous recommendations, as that the museums of a district should combine to hold a district loan exhibition; that museums should distribute their surplus material, and render their research material more available for workers; and that they should prepare educational exhibits for circulation to schools and to towns or villages unprovided with a museum.

This last was the subject of two papers by Dr. T. W. Woodhead, of Huddersfield, and Mr. W. C. Sprunt, of Batley, who described the kind of exhibits sent out, the mode of packing, and the system of distribution. It was pointed out in the discussion that museums had been doing this work long before the libraries took it up. There has, however, been no systematic attempt to provide branch museums in the villages for those of more mature years, at least so far as Great Britain is concerned. The numerous rural museums in Sweden, of which Dr. Klein of the Northern Museum gave an entertaining account, are independent folk museums of high value in promoting local patriotism but not educational in the formal sense. The same may be said of the Heimatmuseen, now springing up all over Germany, of which the ideals were eloquently expounded by Dr. Otto Lehmann.

The more usual type of small museum was in the minds of Dr. F. J. North and Mr. H. A. Hyde, who showed what it might usefully exhibit in geology and botany respectively. The affiliation of such museums to a central museum was discussed by Dr. Cyril Fox, from his experience as director of the National Museum of Wales. He had found the chief difficulty in any scheme to be the lack of a permanent and competent curator ; the parent museum could neither lend nor give material to a museum that was unable to care for it.

The Carnegie Trustees had sent their assistant secretary, Mr. A. B. Hyslop, to glean suggestions that might help towards some scheme of museum extension to rural areas. They were hoping to take counsel with the County Directors of Education and with the Circulation Department of the Victoria and Albert Museum ; but it is clear that the burden of the work

No. 3167, VoL. 126] 